\title{
Knowledge, Attitudes, Practices, and Misconceptions towards COVID-19 among Sub-Sahara Africans
}

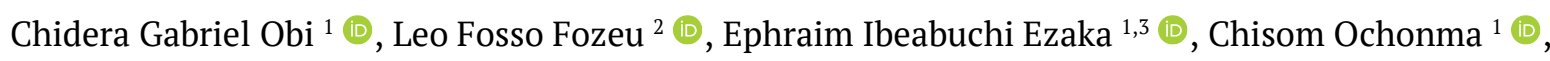 \\ Robert Kamwela ${ }^{4,5 *}$ (1)
}

\footnotetext{
${ }^{1}$ Department of Parasitology and Entomology, Nnamdi Azikiwe University, Awka, NIGERIA

${ }^{2}$ Bafmen Sub-Divisional Hospital, Northwest Region, CAMEROON

${ }^{3}$ Department of Medical Laboratory Technology, College of Health Technology, Adamawa, NIGERIA

${ }^{4}$ Department of Economics, University of Malawi, Zomba, MALAWI

${ }^{5}$ Institute of Development Policy and Management, University of Antwerp, Antwerp, BELGIUM

*Corresponding Author: robertkamwela@gmail.com
}

Citation: Obi, C. G., Fozeu, L. F., Ezaka, E. I., Ochonma, C. and Kamwela, R. (2022). Knowledge, Attitudes, Practices, and Misconceptions towards COVID-19 among Sub-Sahara Africans. European Journal of Environment and Public Health, 6(1), em0101. https://oi.org/10.21601/ejeph/11559

\section{ARTICLE INFO}

Received: 13 Oct. 2021

Accepted: 4 Jan. 2022

\begin{abstract}
Background: COVID-19 is a viral disease that can be transmitted from one person to another. The virus was first reported in Wuhan, China in 2019 and Nigeria recorded the first case of COVID-19 in Sub-Sahara Africa in 2020. The right knowledge, attitudes, and practices are essential in curbing the spread of the virus. Hence, the study was conducted to assess the level of knowledge, attitude, practice, and misconception of Sub-Sahara Africa towards COVID-19 and identifying the factors associated with COVID-19.

Method: An online cross-sectional survey was conducted among respondents from Sub-Sahara Africa from December 2020 to June 2021. This study involved respondents from six African countries, the responses were gotten from Kenya and Sudan (representing East Africa) Nigeria and Ghana (representing West Africa), Cameroon (representing Central Africa), and Malawi (representing Southern Africa). Data collected was analyzed using IBM SPSS version 26.0.

Results: A total of 913 respondents participated in this study with the majority of the age group coming from 21$30(70.9 \%)$. The result indicates that the majority have a good level of knowledge (89.9\%) and attitude (97.7\%) with an insufficient level of practice (61\%). Also, the majority of the respondents had an acceptable level of misconception (84\%). 67\% of the respondents believe that $5 \mathrm{G}$ causes COVID-19. The majority of the respondents reckon that everyone should wear a facemask (90.3\%) and that alcohol does not cure COVID-19 (85.9\%).

Conclusions: The study suggests that Sub-Sahara Africans have adequate knowledge and Attitude without sufficient practice towards COVID-19. Improved policies, awareness and sensitization campaigns should be carried out by government and social media companies to ensure adequate practice towards COVID-19. Furthermore, these findings should be considered by policymakers to implement interventions for outbreaks.
\end{abstract}

Keywords: COVID-19, Sub-Sahara Africa, pandemic, misconceptions, outbreak, knowledge, attitude, practice

\section{BACKGROUND}

COVID-19 is a viral disease that has infected and affected people worldwide. The virus was first discovered on 31st December 2019 at Wuhan, China, and was declared a pandemic on 11th March 2020 by World Health Organization (WHO) (Lee et al., 2021; Reuben et al., 2021). COVID-19 is a zoonotic disease that can be transmitted from one person to another (Zhou et al., 2020) and affects the lower respiratory tract of humans resulting in symptoms such as fever, cough, fatigue, and dyspnea (Adhikari et al., 2020; Huang et al., 2020). The virus affects everyone with older individuals and those with underlying health conditions having a higher risk (Clark et al., 2020).

There are four regions (East, West, Central, and Southern Africa) in Sub-Sahara Africa (SSA) consisting of 46 countries. SSA countries have been subjected to various emerging viral diseases such as lassa fever and ebola which despite its health burden have provided SSA with various expertise, research laboratories, and establishments such as the Africa Center for Disease Control and Prevention (CDC) and research facilities (Adepoju, 2020; Osseni, 2020). These research laboratories, expertise, and establishments were essential in the prompt response to COVID-19 in the region (Abayomi et al., 2021; Umviligihozo et al., 2020). The first COVID-19 case in SSA was reported in Nigeria on 28th January 2020 (Adepoju, 2020). SSA 


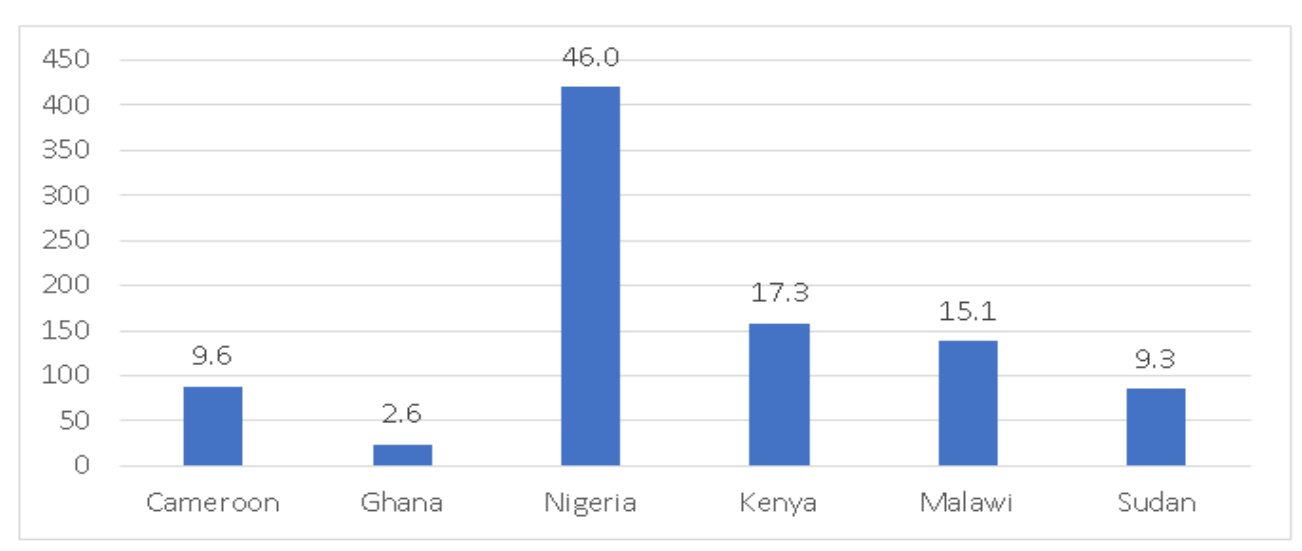

Figure 1. Geographic distribution of study population

countries took preventive measures such as COVD-19 awareness campaigns, restriction of movements and border closure (Osseni, 2020). These countries also partnered with private institutions to control the pandemic. For instance, In Uganda, automotive manufacturer Kiira Motors Corporation teamed up with the Makerere School of Public Health to develop inexpensive ventilators for critically ill coronavirus patients, researchers from Pasteur Institute in Senegal developed a cheap and quick diagnostic test for the virus and there was enthusiasm from private institutions to produce ventilators in Ghana and South Africa (Osseni, 2020).

The success of preventive measures towards the COVID-19 pandemic is largely dependent on public knowledge and adherence to these measures (Al-Hanawi et al., 2020; Singh et al., 2011). During health crises, a proportion of knowledge acquired is false and is usually gotten from social media (dos Santos, 2021). False information can lead to misconception towards COVID-19 increasing the spread of the virus. Measures such as disproving myths and raising public awareness are essential in reducing the spread of COVID-19 (Khadka et al., 2020). Consequently, this study is aimed at assessing the level of knowledge, attitudes, practices, and misconceptions of Sub-Sahara Africa towards COVID-19 and identifying the factors associated with it.

\section{METHOD}

The study is a cross-sectional survey within six countries (Nigeria, Cameroon, Malawi, Kenya, Sudan, and Ghana) of Sub-Sahara Africa. The survey was carried out from December 2020 to June 2021 using an online questionnaire (Google form) which included a consent form. All survey questions were made mandatory was translated into three languages (English, French, and Arabic). It was disseminated through WhatsApp, Facebook, LinkedIn, and other social media platforms with a message encouraging the respondents to share to more respondents leading to a wider reach. The study population was individuals with access to the Internet and Gmail.

The questionnaire contained 32 questions divided into four sections (socio-demographic characteristics, knowledge, attitude, and practice) with mostly close-ended questions. The questionnaires were drafted from previous studies (Ngwewondo et al., 2020; Pal et al., 2020; Peng et al., 2020; Zhong et al., 2020) and modified to suit our objective. WHO
(2020) articles on myths about COVID-19 served as guideline for drafting the misconceptions about COVID-19. Thereafter, it was inserted into knowledge, attitude, and practice sections to prevent bias.

A true, false, and I do not know basis was used in answering the knowledge questions with 1 point for true and 0 for both false and I do not know. Bloom's cut-off method was used to determine the ideal cut-off point for each category of knowledge (poor, insufficient, good, and very god). The Likert approach was used to measure the respondent's Attitude and Practices and the order of responses switched to prevent the positive response from always occupying the first position. The positive attitude/practice was given 2 points, neutral 1 point, and negative attitude 0 points. Bloom's cut-off was also used for attitude and practice.

Data collected was exported to Microsoft Excel 2016 for cleaning. All data were analyzed using IBM SPSS Statistics for Windows, version 26.0 (IBM Corp., Armonk, NY, USA). We assessed the distribution of continuous variables using histograms, probability distribution plots, and the ShapiroWilk test. Continuous variables with a normal distribution were described using means \pm standard deviations (SD) while the medians and interquartile ranges (IQR) were used for skewed variables. Categorical variables were reported as counts and percentages. The Chi-square test was used to compare categorical variables, while the Mann Whitney $U$ and Kruskal Wallis tests were used for comparing medians of continuous variables between groups. Variables with a p-value less than 0.2 after bivariate analysis were included in models for multivariate analysis. Multiple linear regression was done for factors associated with knowledge, attitude, and practice while a binary logistic regression was used for factors associated with a high degree of misconceptions. A p-value less than 0.05 was considered statistically significant.

\section{RESULTS}

\section{Geographic Distribution of Study Population}

Figure 1 presents a sample of 913 valid responses with 444 (48.6\%) responses coming from West Africa (Nigeria and Ghana), 182 (26.6\%) responses from East Africa (Kenya and Sudan), 138(15.1\%) from Southern Africa (Malawi), and 88(9.6\%) from Central Africa (Cameroon). 
Table 1. Sociodemographic characteristics

\begin{tabular}{|c|c|c|c|}
\hline Variable & Category & Number & Percentage \\
\hline \multirow{6}{*}{ Age(years) } & $\leqslant 20$ & 103 & 11.3 \\
\hline & $21-30$ & 647 & 70.9 \\
\hline & $31-40$ & 113 & 12.4 \\
\hline & $41-50$ & 31 & 3.4 \\
\hline & $51-60$ & 17 & 1.9 \\
\hline & $61-70$ & 2 & 0.2 \\
\hline \multirow{4}{*}{ Marital status } & Married & 196 & 21.5 \\
\hline & Single & 710 & 77.8 \\
\hline & Divorced & 6 & 0.7 \\
\hline & Widow (er) & 1 & 0.1 \\
\hline \multirow{4}{*}{ Level of education } & No formal & 4 & 0.4 \\
\hline & Primary & 3 & 0.3 \\
\hline & Secondary & 58 & 6.4 \\
\hline & Tertiary & 848 & 92.9 \\
\hline \multirow{7}{*}{ Occupation } & Unemployed & 105 & 11.5 \\
\hline & Student & 306 & 33.5 \\
\hline & Housewife & 2 & 0.2 \\
\hline & Self-employed & 120 & 13.1 \\
\hline & Private sector & 172 & 18.8 \\
\hline & Public sector & 69 & 7.6 \\
\hline & Healthcare & 139 & 15.2 \\
\hline \multirow{5}{*}{ Working environment } & Home & 135 & 14.8 \\
\hline & Office & 239 & 26.2 \\
\hline & Hospital & 112 & 12.3 \\
\hline & Another frontline worker & 60 & 6.6 \\
\hline & Student/unemployed & 367 & 40.2 \\
\hline
\end{tabular}

Mean age $\pm \mathrm{SD}=26.99 \pm 7.17$

Table 2. Evaluation of knowledge on COVID-19

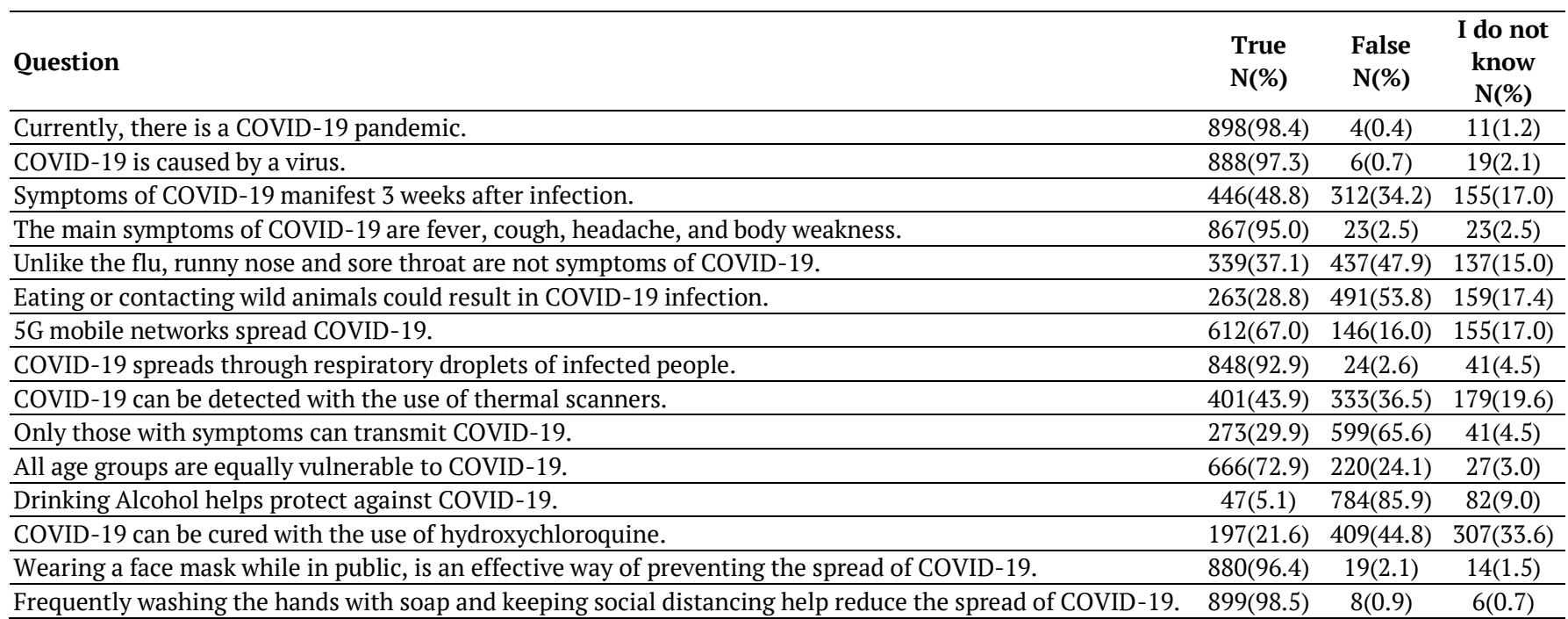

\section{Sociodemographic Characteristics}

The mean age of the respondents was $26.99 \pm 7.17$. The majority of the respondents have gotten to the tertiary level of education (92.9\%), 15.2\% were healthcare workers while $18.9 \%$ worked in either a hospital or other healthcare setting. Other Sociodemographic characteristics can be seen in Table 1.

\section{Evaluation of Knowledge on COVID-19}

The majority of the respondents agreed that there is a COVID-19 pandemic (98.4\%) and $97.3 \%$ stated that it is caused by a virus. $95.0 \%$ believe the main symptoms of COVID-19 to be fever, cough, headache, and body weakness and $92.9 \%$ believe COVID-19 is spread through respiratory droplets of infected people. $65.6 \%$ of respondents believe that there can be an asymptomatic transmission of COVID-19 and $85.9 \%$ disagree that alcohol protects against COVID-19. 96.4\% believe that wearing of facemask is an effective way of preventing COVID-19. The knowledge of the respondents on COVID-19 can be seen in Table 2.

\section{Evaluation of Attitude Towards COVID-19}

92.1\% of respondents believe COVID-19 is real with $93.9 \%$ of the respondents stating that if they protect themselves, they can avoid getting infected. $91.5 \%$ of respondents believe Africa will win the fight against COVID-19. $72.3 \%$ of the respondents 
Table 3. Evaluation of attitude towards COVID-19

\begin{tabular}{|c|c|c|}
\hline Variable & Number & Percentage \\
\hline \multicolumn{3}{|l|}{ In your opinion, is COVID-19 real? } \\
\hline No, It is a hoax. & 20 & 2.2 \\
\hline I do not know. & 52 & 5.7 \\
\hline Yes, it is. & 841 & 92.1 \\
\hline \multicolumn{3}{|c|}{ What do you think about the risk human to human transmission of COVID-19 poses? } \\
\hline I can avoid it if I protect myself. & 857 & 93.9 \\
\hline I do not care. I feel fine. & 20 & 2.2 \\
\hline I am panicked and do not know what to do. & 36 & 3.9 \\
\hline \multicolumn{3}{|l|}{ What is your opinion on the wearing of face masks in public? } \\
\hline It is useless and dangerous for our health. & 16 & 1.8 \\
\hline I do not need to wear one, but I will not discourage others. & 73 & 8.0 \\
\hline Everybody should wear one when in public. & 824 & 90.3 \\
\hline \multicolumn{3}{|l|}{ Do you believe Africa can win the fight against COVID-19? } \\
\hline Yes, if we all respect barrier measures. & 835 & 91.5 \\
\hline Maybe. & 63 & 6.9 \\
\hline No, COVID-19 was sent to destroy Africa. & 15 & 1.6 \\
\hline \multicolumn{3}{|c|}{ In your opinion, do you think the reported cases of COVID-19 is lower than that of other countries? } \\
\hline Yes. & 660 & 72.3 \\
\hline No. & 107 & 11.7 \\
\hline I do not know. & 146 & 16.0 \\
\hline \multicolumn{3}{|l|}{ If yes, then why? $(n=660)$} \\
\hline The climatic condition is unfavorable for COVID-19 to thrive in Africa. & 195 & 29.6 \\
\hline Cases of COVID-19 in Africa are under-reported. & 126 & 19.1 \\
\hline Very few individuals have been tested for COVID-J9 in Africa. & 278 & 42.1 \\
\hline COVID-19 is a government scam, it does not exist. & 27 & 4.1 \\
\hline It is because of prayers. & 30 & 4.5 \\
\hline It is because of our skin colour. & 4 & 0.6 \\
\hline
\end{tabular}

Table 4. Evaluation of practices concerning COVID-19

\begin{tabular}{|c|c|c|}
\hline Variable & Number & Percentage \\
\hline \multicolumn{3}{|l|}{ How often do you wear a face mask when in public? } \\
\hline Never. & 14 & 1.5 \\
\hline Sometimes. & 458 & 50.2 \\
\hline Always. & 441 & 48.3 \\
\hline \multicolumn{3}{|l|}{ Do you maintain social distancing (6 feet at least) in public ? } \\
\hline All the time. & 204 & 22.3 \\
\hline Most of the time. & 483 & 52.9 \\
\hline Rarely. & 226 & 24.8 \\
\hline \multicolumn{3}{|l|}{ Do you wash your hands after touching a surface? } \\
\hline Yes, using soap or alcohol-based sanitizer. & 136 & 14.9 \\
\hline Yes, using a hand dryer or UV light. & 259 & 28.4 \\
\hline No, I do not. & 518 & 56.7 \\
\hline \multicolumn{3}{|l|}{ What do you do if you have flu-like symptoms (fever, headache, cough, etc.)? } \\
\hline Nothing, continue my normal activities. & 791 & 86.6 \\
\hline Stay at home and drink concoctions (garlic, ginger, turmeric, lime, pepper, etc.). & 20 & 2.2 \\
\hline Seek for medical opinion or go to the hospital. & 102 & 11.2 \\
\hline
\end{tabular}

believe COVID-19 is under-reported in Africa with $42.1 \%$ of these respondents believing it is a result of low testing as shown in Table 3.

\section{Evaluation of Practices Concerning COVID-19}

As shown in Table 4, 48.3\% of the respondents always wore a facemask and $1.5 \%$ respondents do not wear a facemask. The majority of the respondents (77.7\%) maintain social distancing most or all of the time. $56.7 \%$ of the respondents do not wash their hands after touching a surface. When respondents have flu-like symptoms, $86.6 \%$ continue with their daily activities, $11.2 \%$ seek medical help and $2.2 \%$ seek self-help.
Level of Knowledge, Attitude, and Practice Towards COVID-19

Figure 2 shows that majority of the respondents had knowledge and attitude of COVID-19 with levels of $77 \%$ and $94.5 \%$ respectively. The level of practice of the respondents was majorly inappropriate (61.1\%).

\section{Assessment of Misconceptions on COVID-19}

$67 \%$ of the respondents believe COVID-19 can be spread through $5 \mathrm{G}$ networks. The majority of the respondents (43.9\%) believe COVID-19 can be detected with the use of thermal scanners while $44.8 \%$ of the respondents believe COVID-19 can be cured by taking hydroxychloroquine. The rest of the misconception can be seen in Table 5 . 


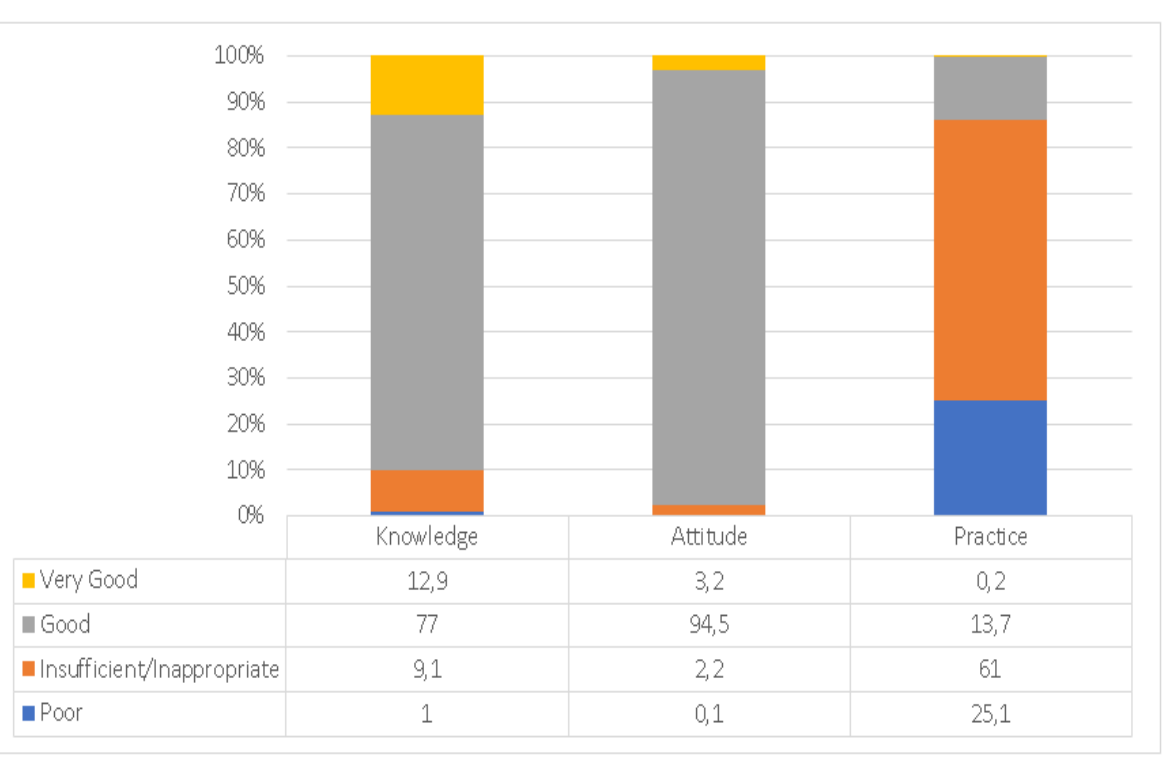

Figure 2. Level of knowledge, attitude, and practice towards COVID-19

Table 5. Assessment of misconceptions on COVID-19

\section{Variable}

5G mobile networks spread COVID-19.

\begin{tabular}{lc}
\hline True. & 612 \\
\hline False. & 146 \\
\hline I do not know. & 155 \\
\hline COVID-19 can be detected with the use of thermal scanners. &
\end{tabular}

\section{COVID-19 can be detected with the use of thermal scanners.}

\begin{tabular}{|c|c|c|}
\hline True. & 401 & 43.9 \\
\hline False. & 333 & 36.5 \\
\hline I do not know. & 179 & 19.6 \\
\hline \multicolumn{3}{|l|}{ Only those with symptoms can transmit COVID-19. } \\
\hline True. & 273 & 29.9 \\
\hline False. & 599 & 65.6 \\
\hline I do not know. & 41 & 4.5 \\
\hline \multicolumn{3}{|l|}{ Drinking alcohol helps protect against COVID-19. } \\
\hline True. & 47 & 5.1 \\
\hline False. & 784 & 85.9 \\
\hline I do not know. & 82 & 9.0 \\
\hline \multicolumn{3}{|l|}{ COVID-19 can be cured with the use of hydroxychloroquine. } \\
\hline True. & 197 & 21.6 \\
\hline False. & 409 & 44.8 \\
\hline I do not know. & 307 & 33.6 \\
\hline \multicolumn{3}{|l|}{ What is your opinion on the wearing of face masks in public? } \\
\hline It is useless and dangerous for our health. & 16 & 1.8 \\
\hline I do not need to wear one, but I won't discourage others. & 73 & 8.0 \\
\hline Everybody should wear one when in public. & 824 & 90.3 \\
\hline \multicolumn{3}{|l|}{ Why are reported cases lower in Africa? } \\
\hline The climate is unfavorable for COVID-19 to thrive in Africa. & 195 & 29.5 \\
\hline Cases of COVID-19 in Africa are under-reported. & 126 & 19.1 \\
\hline Very few individuals have been tested. & 278 & 42.1 \\
\hline COVID-19 is a government scam, it does not exist. & 27 & 4.1 \\
\hline It is because of prayers. & 30 & 4.5 \\
\hline It is because of our skin colour. & 4 & 0.6 \\
\hline \multicolumn{3}{|l|}{ Do you wash your hands after touching a surface? } \\
\hline Yes, using soap or alcohol-based sanitizer. & 136 & 14.9 \\
\hline Yes, using hand dryer or UV light. & 259 & 28.4 \\
\hline No, I do not. & 518 & 56.7 \\
\hline \multicolumn{3}{|l|}{ What do you do if you have flu-like symptoms? } \\
\hline Nothing, continue my normal activities. & 791 & 86.6 \\
\hline Stay at home and drink concoctions. & 20 & 2.2 \\
\hline Seek for medical opinion or go to the hospital. & 102 & 11.2 \\
\hline
\end{tabular}




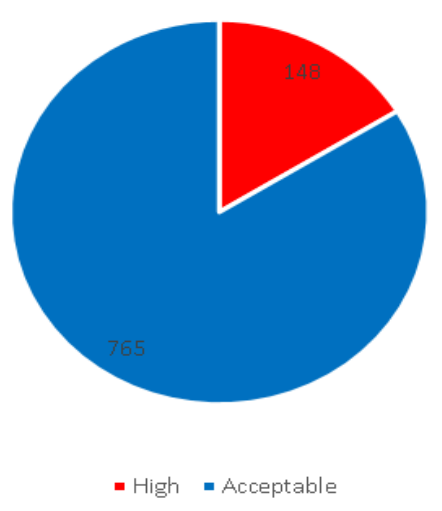

Figure 3. Degree of misconception

Table 6. Sociodemographic characteristics associated with knowledge, attitude, and practice

\begin{tabular}{|c|c|c|c|c|c|c|}
\hline Variables & $\begin{array}{c}\text { Knowledge } \\
\text { Median (IQR) } \\
\end{array}$ & p-value & $\begin{array}{c}\text { Attitude } \\
\text { Median (IQR) } \\
\end{array}$ & p-value & $\begin{array}{c}\text { Practice } \\
\text { Median (IQR) } \\
\end{array}$ & p-value \\
\hline \multicolumn{7}{|l|}{ Country of residence } \\
\hline Cameroon & $10(9-11)$ & \multirow{6}{*}{$<0.001$} & $8.5(8-10)$ & \multirow{6}{*}{0.072} & $3(2-4)$ & \multirow{6}{*}{$<0.001$} \\
\hline Ghana & $10(9-11)$ & & $8(7.5-10)$ & & $3(3-4)$ & \\
\hline Kenya & $10(9-12)$ & & $8(7-10)$ & & $4(3-4)$ & \\
\hline Malawi & $11(9-13)$ & & $10(8-10)$ & & $3(3-4)$ & \\
\hline Nigeria & $10(8-11)$ & & $8(7-10)$ & & $3(2-4)$ & \\
\hline Sudan & $12(10-13)$ & & $8(6-10)$ & & $4(3-4)$ & \\
\hline \multicolumn{7}{|l|}{ Gender } \\
\hline Male & $10(9-12)$ & \multirow{2}{*}{0.687} & $9(7-10)$ & \multirow{2}{*}{0.058} & $3(2-4)$ & \multirow{2}{*}{0.075} \\
\hline Female & $10(9-12)$ & & $8(7-10)$ & & $3(3-4)$ & \\
\hline \multicolumn{7}{|l|}{ Age (years) } \\
\hline$\leqslant 20$ & $10(8-11)$ & \multirow{4}{*}{$<0.001$} & $8(7-9)$ & \multirow{4}{*}{$<0.001$} & $3(2-4)$ & \multirow{4}{*}{0.310} \\
\hline $21-30$ & $10(9-12)$ & & $8(7-10)$ & & $3(3-4)$ & \\
\hline $31-40$ & $11(9-12)$ & & $9(8-10)$ & & $3(3-4)$ & \\
\hline$>40$ & $11(9-12)$ & & $10(8-10)$ & & $3(3-4)$ & \\
\hline \multicolumn{7}{|l|}{ Marital status } \\
\hline Married & $11(9-12)$ & \multirow{2}{*}{$<0.001$} & $10(7.5-10)$ & \multirow{2}{*}{0.008} & $3(3-4)$ & \multirow{2}{*}{0.729} \\
\hline Single & $10(9-11)$ & & $8(7-10)$ & & $3(2-4)$ & \\
\hline \multicolumn{7}{|l|}{ Level of education } \\
\hline Secondary and below & $9(8-10)$ & \multirow{2}{*}{$<0.001$} & $8(7-10)$ & \multirow{2}{*}{0.043} & $3(3-4)$ & \multirow{2}{*}{0.790} \\
\hline Tertiary & $10(9-12)$ & & $8(7-10)$ & & $3(2-4)$ & \\
\hline \multicolumn{7}{|l|}{ Occupation } \\
\hline Unemployed & $10(9-11)$ & \multirow{6}{*}{$<0.001$} & $8(7-10)$ & \multirow{6}{*}{$<0.001$} & $3(3-4)$ & \multirow{6}{*}{0.392} \\
\hline Student & $10(8-11)$ & & $8(7-10)$ & & $3(2-4)$ & \\
\hline Self-employed & $9(8-11)$ & & $8(7-10)$ & & $3(3-4)$ & \\
\hline Private sector & $11(9-12)$ & & $9.5(8-10)$ & & $3(3-4)$ & \\
\hline Public sector & $11(9-12)$ & & $8(8-10)$ & & $3(2-4)$ & \\
\hline Healthcare & $12(11-13)$ & & $10(8-10)$ & & $3(2-4)$ & \\
\hline \multicolumn{7}{|l|}{ Working environment } \\
\hline Home & $10(9-11)$ & \multirow{5}{*}{$<0.001$} & $8(7-10)$ & \multirow{5}{*}{0.002} & $4(3-4)$ & \multirow{5}{*}{0.058} \\
\hline Office & $10(9-12)$ & & $9(8-10)$ & & $3(3-4)$ & \\
\hline Hospital & $12(11-13)$ & & $10(8-10)$ & & $3(2-4)$ & \\
\hline Another frontline worker & $11(9-12)$ & & $8(7-10)$ & & $3(3-4)$ & \\
\hline Student/unemployed & $10(8-11)$ & & $8(7-10)$ & & $3(2-4)$ & \\
\hline
\end{tabular}

\section{Evaluation of the Degree of Misconceptions}

The degree of misconception among the respondents is 83.8\% normal and 16.2\% high as shown in Figure 3.

\section{Sociodemographic Characteristics Associated with Knowledge, Attitude, and Practice}

The countries of residence, age, and marital status of the respondents had a significant relationship with the knowledge and practice at the univariate level of analysis and was Insignificant at the multivariate level of analysis (Table 6). The gender of respondents, level of education, and occupation had a significant relationship with attitude and practice at the univariate and multivariate levels of analysis. Table 7 shows the estimation of the relationship between sociodemographic characteristics and knowledge, attitude and practice using using multiple linear regression. 
Table 7. Estimation of the relationship between sociodemographic characteristics and knowledge, attitude, and practice

\begin{tabular}{|c|c|c|c|c|c|c|}
\hline \multirow{2}{*}{ Variables } & \multicolumn{2}{|l|}{ Knowledge } & \multicolumn{2}{|l|}{ Attitude } & \multicolumn{2}{|l|}{ Practice } \\
\hline & $\mathrm{B}(95 \% \mathrm{CI})$ & $p$-value & $\mathrm{B}(95 \% \mathrm{CI})$ & $\mathrm{p}$-value & $\mathrm{B}(95 \% \mathrm{CI})$ & p-value \\
\hline Country of residence & $0.001(-0.099-0.099)$ & 0.997 & $-0.073(-0.151-0.004)$ & 0.065 & $-0.078(-0.154-0.002)$ & 0.044 \\
\hline Age (years) & $0.032(-0.184-0.247)$ & 0.772 & $0.141(-0.028-0.311)$ & 0.103 & 1 & 1 \\
\hline Gender & 1 & 1 & $-0.146(-0.358-0.066)$ & 0.178 & $-0.185(-0.397-0.028)$ & 0.089 \\
\hline Marital status & $-0.333(-0.692-0.026)$ & 0.069 & $-0.045(-0.326-0.237)$ & 0.755 & 1 & 1 \\
\hline Level of education & $1.032(0.621-1.444)$ & $<0.001$ & $0.279(-0.044-0.601)$ & 0.090 & 1 & 1 \\
\hline Occupation & $0.343(0.264-0.423)$ & $<0.001$ & $0.095(0.033-0.158)$ & 0.003 & 1 & 1 \\
\hline Working environment & $0.187(0.081-0.294)$ & 0.001 & $0.027(-0.057-0.110)$ & 0.531 & $-0.072(-0.140-0.004)$ & 0.039 \\
\hline
\end{tabular}

/: Not included in the model

Table 8. Sociodemographic characteristics associated with a high degree of misconceptions on COVID-19

\begin{tabular}{|c|c|c|c|c|}
\hline \multirow{2}{*}{ Variable } & \multicolumn{2}{|c|}{ Degree of misconception } & \multirow{2}{*}{$\begin{array}{l}\text { Odds ratio } \\
\text { (95\% CI) }\end{array}$} & \multirow{2}{*}{ p-value } \\
\hline & High n (\%) & Normal n (\%) & & \\
\hline \multicolumn{5}{|l|}{ Country of residence } \\
\hline Cameroon & $18(20.5)$ & $70(79.5)$ & $1.375(0.793-2.385)$ & 0.256 \\
\hline Ghana & $3(12.5)$ & $21(87.5)$ & $0.733(0.216-2.490)$ & 0.784 \\
\hline Kenya & $18(11.4)$ & $140(88.6)$ & $0.618(0.365-1.046)$ & 0.071 \\
\hline Malawi & $15(10.9)$ & $123(89.1)$ & $0.589(0.334-1.038)$ & 0.065 \\
\hline Nigeria & $89(21.2)$ & $331(78.8)$ & $1.978(1.382-2.832)$ & $<0.001$ \\
\hline Sudan & $5(5.9)$ & $80(94.1)$ & $0.299(0.119-0.752)$ & 0.007 \\
\hline \multicolumn{5}{|l|}{ Gender } \\
\hline Male & $68(17.1)$ & $330(82.9)$ & \multirow{2}{*}{$1.120(0.787-1.596)$} & \multirow{2}{*}{0.528} \\
\hline Female & $80(15.5)$ & $435(84.5)$ & & \\
\hline \multicolumn{5}{|l|}{ Age (years) } \\
\hline$\leqslant 20$ & $17(16.5)$ & $86(83.5)$ & $1.025(0.589-1.781)$ & 0.931 \\
\hline $21-30$ & $104(16.1)$ & $543(83.9)$ & $0.966(0.657-1.421)$ & 0.862 \\
\hline $31-40$ & $18(15.9)$ & $95(84.1)$ & $0.977(0.570-1.672)$ & 0.931 \\
\hline$>40$ & $9(18.0)$ & $41(82.0)$ & $1.143(0.543-2.406)$ & 0.724 \\
\hline \multicolumn{5}{|l|}{ Marital status } \\
\hline Married & $29(14.8)$ & $167(85.2)$ & \multirow{2}{*}{$0.873(0.562-1.356)$} & \multirow{2}{*}{0.544} \\
\hline Single & $119(16.6)$ & $598(83.4)$ & & \\
\hline \multicolumn{5}{|l|}{ Level of education } \\
\hline Secondary and below & $9(13.8)$ & $56(86.2)$ & \multirow{2}{*}{$0.820(0.396-1.696)$} & \multirow{2}{*}{0.592} \\
\hline Tertiary & $139(16.4)$ & $709(83.6)$ & & \\
\hline \multicolumn{5}{|l|}{ Occupation } \\
\hline Unemployed & $23(21.5)$ & $84(78.5)$ & $1.492(0.906-2.457)$ & 0.114 \\
\hline Student & $54(17.6)$ & $252(82.4)$ & $1.169(0.810-1.688)$ & 0.403 \\
\hline Self-employed & $28(23.3)$ & $92(76.7)$ & $1.707(1.072-2.719)$ & 0.023 \\
\hline Private sector & $21(12.2)$ & $151(87.8)$ & $0.672(0.410-1.103)$ & 0.144 \\
\hline Public sector & $10(14.5)$ & $59(85.5)$ & $0.867(0.433-1.737)$ & 0.687 \\
\hline Healthcare & $12(8.6)$ & $127(91.4)$ & $0.443(0.238-0.824)$ & 0.008 \\
\hline \multicolumn{5}{|l|}{ Working environment } \\
\hline Home & $27(20.0)$ & $108(80.0)$ & $1.357(0.853-2.159)$ & 0.196 \\
\hline Office & $39(16.3)$ & $200(83.7)$ & $1.011(0.678-1.507)$ & 0.958 \\
\hline Hospital & $11(9.8)$ & $101(90.2)$ & $0.528(0.276-1.010)$ & 0.050 \\
\hline Another frontline worker & $8(13.3)$ & $52(86.7)$ & $0.784(0.364-1.686)$ & 0.532 \\
\hline Student/unemployed & $63(17.2)$ & $304(82.8)$ & $1.124(0.787-1.605)$ & 0.521 \\
\hline
\end{tabular}

Sociodemographic Characteristics Associated with a High Degree of Misconceptions on COVID-19

The degree of misconception by respondents from Nigeria, Kenya, and Sudan was significant, being a HealthCare worker and working in the hospital had a significant difference in the degree of misconception (Table 8). Also, working at home and being unemployed had a significant effect on the degree of misconception $(\mathrm{p}=0.196$ and $\mathrm{p}=0.114)$.

\section{Binary Logistic Regression}

Respondents from Nigeria and those who are selfemployed are significant $(\mathrm{p}<0.001$ and $\mathrm{p}=0.031$ ) having a $92.8 \%$
Table 9. Table on top of a column (font size: 9)

\begin{tabular}{lcc}
\hline Variable & Adjusted OR (95\% CI) & p-value \\
\hline Country of residence (Nigeria) & $1.928(1.339-2.775)$ & $<0.001$ \\
\hline Occupation (Self-employed) & $1.682(1.047-2.702)$ & 0.031 \\
\hline Working environment (Hospital) & $0.670(0.345-1.301)$ & 0.237 \\
\hline
\end{tabular}

and a $68.2 \%$ higher odd respectively when compared to reference occupation. Those working in a hospital have a $33 \%$ lower odds than the reference working environment and this is not significant with $\mathrm{p} \leqslant 0.05$ (Table 9). 


\section{DISCUSSION}

Since the outbreak of COVID-19 in Wuhan China, COVID19 has caused severe damage to Global Health and weakened the health capacity of nations. The countries in Sub-Sahara Africa have through various channels disseminated information on COVID-19. However, like any health emergency, the pandemic has generated lots of discussion and mixed reactions around the globe with both facts and misconceptions arising from these discussions. Hence, the right information is necessary for combating global health emergencies such as COVID-19 (Baig et al., 2020).

The responses gotten from Kenya and Sudan (representing East Africa) Nigeria and Ghana (representing West Africa), Cameroon (representing Central Africa), and Malawi (representing Southern Africa) were amalgamated to get the average view of Sub-Sahara Africa. Nigeria had the highest number of respondents which can be attributed to Nigeria having the highest number of internet users in Africa (Internet World Stats, 2020). Nigeria and Cameroon were among the first six Sub-Sahara African countries to report over 40 cases of COVID-19 (Massinga Loembé et al., 2020).

The majority of respondents know that there is a pandemic and COVID-19 is caused by a virus corresponding with researches done by (Qutob and Awartani, 2021; Wu and Munthali, 2021). Almost all the respondents knew the means of reducing the transmission rates, ways of preventing the disease, mode of transmission, and the causative agent of COVID-19 aligning with the works of (Gebretsadik et al., 2021; Shrestha et al., 2021) where the majority had similar knowledge. This can be credited to the effort of various Government and Private Establishments in the circulation of information on COVID-19 in Africa. Sub-Sahara African countries used the invested responses to similar outbreaks in the past to sensitize and raise awareness on COVID-19 (Massinga Loembé et al., 2020).

The research showed that a high number of the respondents had a sufficient level of knowledge towards COVID-19. This aligns with reports of (Hager et al., 2020; Lee et al., 2021) thou disagrees with the findings of (Desalegn et al., 2021) which had a lower level of knowledge. The high level of knowledge can be attributed to the respondents having a high educational level with the majority starting or have finished tertiary education and within the age group of 21-30. This age bracket has the highest internet usage (Chiedozie et al., 2021; Pew Research Center, 2021) and the Internet is a common source of COVID-19 information (Erinoso et al., 2021; Olaimat et al., 2020). The significant positive association between the age and level of education with the level of knowledge supports this assumption.

Assessment of the level of Attitude towards COVID-19 showed that the respondents had a high attitude towards COVID-19. 93.9\% of them believe they can protect themselves from COVID-19, agreeing with the findings of (Pal et al., 2020). This can be attributed to the various information that has been passed across on the various means of transmitting COVID-19. 91.3\% of the respondents acknowledged that in addition to other preventive measures, wearing a facemask in public will curtail the spread and enable Africa to win the fight against
COVID-19. This belief can be ascribed to successful control of recent outbreaks such as Ebola in Africa. Similar researches in Nigeria (Isah et al., 2020), Ethiopia (Aynalem et al., 2021), and Tanzania (Rugarabamu et al., 2020) also showed the belief of the respondents in the control of COVID-19.

72.3\% of the respondents believe that cases of COVID-19 in Africa are low with $29.6 \%, 42.1 \%$, and $19.1 \%$ attributing it to the climatic conditions, low testing, and under-reporting of cases respectively. On the other hand, Chitungo et al. (2020) reckoned that low testing and under-reporting of cases should not be strictly taken as the major causes of low cases in Africa because most African governments showed the political will to put measures in place at the onset of the pandemic. Chitungo et al. (2020) also agreed with Hopman et al. (2020) that climatic conditions can affect the low cases thou there is no evidence backing it. Furthermore, Ukaga et al. (2021) state that there is no miscalculation of mortality in the reported cases.

The level of practice among the respondents was low with poor and insufficient practices accounting for $86.1 \%$ of the respondents. This low level of practice towards COVID-19 is worrisome as there is a high level of knowledge and Attitude towards COVID-19. This low level of practice is similar to studies in Malawi (Li et al., 2021) and Nigeria (Habib et al., 2021). The majority of the respondents do not wear facemasks always in public. Washing of hands after touching surfaces was ignored by the majority of respondents, this can be due to behavioral patterns and inadequate Water Sanitation Hygiene (WASH) facilities in the region. The availability of water affects the rate of handwashing (Dagne et al., 2018). 86.6\% of the respondents continue with their normal activities when they have flu-like symptoms. This aligns with (Tartari et al., 2020), a global survey carried out before the COVID-19 pandemic. The study also showed that less than $12 \%$ of the respondents went to the hospital when they have flu-like symptoms. Selfmedication by using substances like garlic was very minimal.

Outbreaks are associated with various misconceptions which are spread both orally and through social media. The degree of misconception among the respondents was normal. $67 \%$ of the respondents believe COVID-19 can be spread through 5G networks which disagrees with the report of (Ovenseri-Ogbomo et al., 2020). This can be linked to various conspiracy theories that have been distributed on various social media platforms since the inception of the COVID-19 pandemic. These conspiracy theories are mostly publicized by fake websites (Bruns et al., 2020). These theories most times play on the emotions of the readers.

Respondents who have started or finished their tertiary level had a higher level of misconception than those who have a secondary school certificate or less. This disagrees with previous research by Isah et al. (2020) in Nigeria. This is surprising as it is presumed that a higher level of education ensures the ability to analyze information better. The healthcare workers had the lowest percentage of high misconception which is unsurprising as they have a more association with COVID-19 and other diseases. Singles had a higher level of misconception. This can be linked to singles spending more on the internet than married individuals (Bondah and Agyemang, 2020), and the internet as the greatest source of information on COVID-19 including misconceptions 
can be inferred as the reason for a higher level of misconception among singles.

$43.9 \%$ of the respondents also believe COVID-19 can be detected through thermal scanners. This misconception can be attributed to the use of thermal scanners at all entry points and parastatals following the outbreak of COVID-19. This misconception can pose a health risk as not everyone with COVID-19 will have a high fever. A COVID-19 screening test is recommended in addition to thermal scanning (Nsawotebba et al., 2021). $65.6 \%$ of the respondents believe in the asymptomatic transmission of COVID-19. This knowledge will help people to maintain the correct safety measures even when around people without symptoms. A greater part of respondents believes Alcohol does not prevent COVID-19 neither does chloroquine cure COVID-19. The level of misconception is normal which is lower than similar researches (Baig et al., 2020; Bakebillah et al., 2021) where more than half of the respondents have a poor score of misconception. Irrespective of this normal level of misconception, there is still more to be done in terms of reducing misconceptions of people towards COVID-19.

The study also explored the relationship between sociodemographic characteristics and knowledge, attitude, and practices. The level of knowledge, attitude, and practice between the various Socio-demographic characteristics are similar. The country of residence, marital status, level of education, occupation, and working environment were the significant predictors of Knowledge. This corresponds with similar research on COVID-19 (Desalegn et al., 2021; Ngwewondo et al., 2020). As stated by Ngwewondo et al. (2020), these factors will be essential for health workers and policymakers in identifying the target population. The mean level of knowledge among respondents who have started or finished tertiary level of education was higher than those who have not reached tertiary level corresponding with (Al-Hanawi et al., 2020). People who have started or finished tertiary level of education are expected to be more exposed and knowledgeable, hence the higher level of knowledge. It is also important to note that, the level of knowledge among those working in the health sector was highest in the working environment. This aligns with similar studies where the knowledge of COVID-19 among health workers was very high (Ejeh et al., 2020; Kanu et al., 2021).

\section{CONCLUSIONS AND RECOMMENDATIONS}

Although most respondents have basic knowledge, possess a positive attitude, and acceptable level of misconception towards COVID-19, there is an insufficient level of practice towards COVID-19. Therefore, improved polices, awareness and sensitization campaigns are essential in curbing Misconceptions and ensuring positive practice towards curtailing the virus. For instance, Governments in Sub-Sahara Africa should enact policies and liaise with the private sector to ensure that COVID-19 preventive measures are practiced at all times. Financial penalties can be introduced as sanctions to improve COVID-19 related practices. Also, the government should collaborate with telecom operators to disseminate COVID-19 messages promptly to their subscribers. Social media companies should enhance their fact checking operations while search engines should limit information pertaining to COVID-19 from unverified websites. In addition, Governments should distribute COVID-19 information promptly and widely to prevent misinterpretation of the information by rumor mongers.

\section{Limitations}

During the data collection process, some persons were unwilling to click on the link to the online form as they expressed the fear of clicking on scam links thus reducing the number of respondents. Also, the use of an online form of survey prevented people without internet service or smartphones from participating in the survey. The convenience sampling method may have led to recruitment bias and inability to calculate the response rate.

\section{Strength of the Study}

The strength of this research can be seen in its target population as this the first multi-national to investigate the knowledge, attitude, practice and misconception towards COVID-19 related research in Sub-Sahara Africa. We identified the level and analyzed the relationship between sociodemographic characteristics and the knowledge, attitude, practice and misconception towards COVID-19 among SubSahara Africans.

Author contributions: All co-authors have involved in all stages of this study while preparing the final version. They all agree with the results and conclusions.

Funding: No external funding is received for this article.

Declaration of interest: The authors declare that they have no competing interests.

Ethics approval: Not applicable.

Consent to participate: A brief introductory letter was attached to the questionnaire that was used in this study. The informed consent of the respondents was sought and obtained before the commencement of the study.

Availability of data and materials: All data generated or analyzed during this study are available for sharing when appropriate request is directed to corresponding author.

\section{REFERENCES}

Abayomi, A., Balogun, M. R., Bankole, M., Banke-Thomas, A., Mutiu, B., Olawepo, J., et al. (2021). From ebola to COVID19: Emergency preparedness and response plans and actions in Lagos, Nigeria. Global Health, 17(1), 79. https://doi.org/10.1186/s12992-021-00728-X

Adepoju, P. (2020). Nigeria responds to COVID-19; first case detected in Sub-Saharan Africa. Nature Medicine, 26(4), 444-448. https://doi.org/10.1038/d41591-020-00004-2

Adhikari, S. P., Meng, S., Wu, Y.-J., Mao, Y.-P., Ye, R.-X., Wang, Q.-Z., et al. (2020). Epidemiology, causes, clinical manifestation and diagnosis, prevention and control of coronavirus disease (COVID-19) during the early outbreak period: a scoping review. Infectious Diseases of Poverty, 9(1), 29. https://doi.org/10.1186/s40249-020-00646-x 
Al-Hanawi, M. K., Angawi, K., Alshareef, N., Qattan, A. M. N., Helmy, H. Z., Abudawood, Y., et al. (2020). Knowledge, attitude and practice toward COVID-19 among the public in the Kingdom of Saudi Arabia: A cross-sectional study. Front Public Health, 8. https://doi.org/10.3389/fpubh.2020. 00217

Aynalem, Y. A., Akalu, T. Y., Gebresellassie, B., Sharew, N.T. and Shiferaw, W. S. (2021). Assessment of undergraduate student knowledge, practices, and attitude towards COVID-19 in Debre Berhan University, Ethiopia. PloS One, 16(5), e0250444. https://doi.org/10.21203/rs.3.rs-28556/v1

Baig, M., Jameel, T., Alzahrani, S. H., Mirza, A. A., Gazzaz, Z. J., Ahmad, T., et al. (2020). Predictors of misconceptions, knowledge, attitudes, and practices of COVID-19 pandemic among a sample of Saudi population. PLoS One, 15(12), e0243526. https://doi.org/10.1371/journal.pone.0243526

Bakebillah, M., Billah, M. A., Wubishet, B. L. and Khan, M. N. (2021). Community's misconception about COVID-19 and its associated factors in Satkhira, Bangladesh: A crosssectional study. Plos One. https://doi.org/10.1371/journal. pone.0257410

Bondah, E. K. and Agyemang, D. O. (2020). Factors predicting knowledge on COVID-19 misconceptions and perception of government efforts in Ghana: A cross-sectional study. International Journal of Scientific Reports, 6(9), 340. https://doi.org/10.18203/issn.2454-2156. IntJSciRep20203547

Bruns, A., Harrington, S. and Hurcombe, E. (2020). 'Corona? 5G? or both?': The dynamics of COVID-19/5G conspiracy theories on Facebook. Media International Australia, 177(1), 12-29. https://doi.org/10.1177/1329878X20946113

Chiedozie, A. P., Chukwuebuka, O. J., Chidimma, C. F., Gabriel, O. C. and Chioma, U. B. (2021). Willingness to accept a potential COVID-19 vaccine in Nigeria. American Journal of Medical Sciences and Medicine, 9(1), 1-5. https://doi.org/10.12691/ajmsm-9-1-1

Chitungo, I., Dzobo, M., Hlongwa, M. and Dzinamarira, T. (2020). COVID-19: Unpacking the low number of cases in Africa. Public Health Practice, 1, 100038. https://doi.org/ 10.1016/j.puhip.2020.100038

Clark, A., Jit, M., Warren-Gash, C., Guthrie, B., Wang, H. H. X., Mercer, S. W., et al. (2020). Global, regional, and national estimates of the population at increased risk of severe COVID-19 due to underlying health conditions in 2020: A modelling study. The Lancet Global Health, 8(8), e1003-17. https://doi.org/10.1016/S2214-109X(20)30264-3

Dagne, H., Bogale, L., Borcha, M., Tesfaye, A.and Dagnew, B. (2019). Hand washing practice at critical times and its associated factors among mothers of under five children in Debark town, northwest Ethiopia, 2018. The Italian Journal of Pediatrics, 45(1), 120. https://doi.org/10.1186/s13052019-0713-z

Desalegn, Z., Deyessa, N., Teka, B., Shiferaw, W., Hailemariam, D., Addissie, Aa, et al. (2021). COVID-19 and the public response: Knowledge, attitude and practice of the public in mitigating the pandemic in Addis Ababa, Ethiopia. PLoS One, 16(1), e0244780. https://doi.org/10.1371/journal. pone. 0244780 dos Santos, F. O. (2021). Myths and misconceptions on COVID19: 'Congo check' and 'Talato' verification experiences. Frontiers in Communication, 6. https://doi.org/10.3389/ fcomm.2021.627214

Ejeh, F. E., Saidu, A. S., Owoicho, S., Maurice, N. A., Jauro, S., Madukaji, L., et al. (2020). Knowledge, attitude, and practice among healthcare workers towards COVID-19 outbreak in Nigeria. Heliyon, 6(11), e05557. https://doi.org/ 10.1016/j.heliyon.2020.e05557

Erinoso, O., Wright, K. O., Anya, S., Kuyinu, Y., Abdur-Razzaq, H. and Adewuya, A. (2021). Predictors of COVID-19 information sources and their perceived accuracy in Nigeria: Online cross-sectional study. JMIR Public Health and Surveillance, 7(1), e22273. https://doi.org/10.2196/ 22273

Gebretsadik, D., Gebremichael, S. and Belete, M. A. (2021). Knowledge, attitude and practice toward COVID-19 pandemic among population visiting Dessie Health Center for COVID-19 screening, Northeast Ethiopia. Infection and Drug Resistance, 14, 905-915. https://doi.org/10.2147/IDR. S297047

Habib, M. A., Dayyab, F.M., Iliyasu, G. and Habib, A. G. (2021). Knowledge, attitude and practice survey of COVID-19 pandemic in Northern Nigeria. PLoS One, 16(1), e0245176. https://doi.org/10.1371/journal.pone.0245176

Hager, E., Odetokun, I. A., Bolarinwa, O., Zainab, A., Okechukwu, O. and Al-Mustapha, A. I. (2020). Knowledge, attitude, and perceptions towards the 2019 Coronavirus pandemic: A bi-national survey in Africa. PLoS One, 15(7), e0236918. https://doi.org/10.1371/journal.pone.0236918

Hopman, J., Allegranzi, B. and Mehtar, S. Managing COVID-19 in low- and middle-income countries. JAMA, 323(16), 1549. https://doi.org/10.1001/jama.2020.4169

Huang, C., Wang, Y., Li, X., Ren, L., Zhao, J., Hu, Y., et al. (2020). Clinical features of patients infected with 2019 novel coronavirus in Wuhan, China. The Lancet, 395(10223), 497-506. https://doi.org/10.1016/S01406736(20)30183-5

Internet World Stats. (2020). Internet penetration in Africa. Available at: https://www.internetworldstats.com/stats1. htm (Accessed: 14 August 2021).

Isah, M. B., Abdulsalam, M., Bello, A., Ibrahim, M.I., Usman, A., Nasir, A., et al. (2020). Coronavirus disease 2019 (COVID-19): Knowledge, attitudes, practices (KAP) and misconceptions in the general population of Katsina State, Nigeria. medRxiv, 2020.06.11.20127936. https://doi.org/ 10.1101/2020.06.11.20127936

Kanu, S., James, P. B., Bah, A. J., Kabba, J. A., Kamara, M. S., Williams, C. E. E., et al. (2021). Healthcare workers' knowledge, attitude, practice and perceived health facility preparedness regarding COVID-19 in Sierra Leone. The Journal of Multidisciplinary Healthcare, 14, 67-80. https://doi.org/10.2147/JMDH.S287156

Khadka, S., Hashmi, F. K. and Usman, M. (2020). Preventing COVID-19 in low- and middle-income countries. Drugs \& Therapy Perspectives, 36(6), 250-252. https://doi.org/ 10.1007/s40267-020-00728-8 
Lee, M., Kang, B.-A. and You, M. (2021). Knowledge, attitudes, and practices (KAP) toward COVID-19: A cross-sectional study in South Korea. BMC Public Health, 21(1), 295. https://doi.org/10.1186/s12889-021-10285-y

Li, Y., Liu, G., Egolet, R. O., Yang, R., Huang, Y. and Zheng, Z. (2021). Knowledge, attitudes, and practices related to COVID-19 among Malawi adults: A community-based survey. International Journal of Environmental Research and Public Health, 18(8), 4090. https://doi.org/ 10.3390/ijerph18084090

Massinga Loembé, M., Tshangela, A., Salyer, S. J., Varma, J. K., Ouma, A. E. O. and Nkengasong, J. N. (2020). COVID-19 in Africa: The spread and response. Nature Medicine, 26(7), 999-1003. https://doi.org/10.1038/s41591-020-0961-X

Ngwewondo, A., Nkengazong, L., Ambe, L. A., Ebogo, J. T., Mba, F. M., Goni, H. O., et al. (2020). Knowledge, attitudes, practices of/towards COVID-19 preventive measures and symptoms: A cross-sectional study during the exponential rise of the outbreak in Cameroon. PLOS Neglected Tropical Diseases, 14(9), e0008700. https://doi.org/10.1371/journal. pntd.0008700

Nsawotebba, A., Ibanda, I., Ssewanyana, I., Ogwok, P., Ocen, F., Okiira, C., et al. (2021). Effectiveness of thermal screening in detection of COVID-19 among truck drivers at Mutukula Land Point of Entry, Uganda. PLoS One, 16(5), e0251150. https://doi.org/10.1371/journal.pone.0251150

Olaimat, A. N., Aolymat, I., Shahbaz, H. M. and Holley, R. A. (2020). Knowledge and information sources about COVID19 among university students in Jordan: A cross-sectional study. Frontiers in Public Health, 8. https://doi.org/ 10.3389/fpubh.2020.00254

Osseni, I. A. (2020). COVID-19 pandemic in Sub-Saharan Africa: Preparedness, response, and hidden potentials. Tropical Medicine and Health, 48(1), 48. https://doi.org/ 10.1186/s41182-020-00240-9

Ovenseri-Ogbomo, G., Ishaya, T., Osuagwu, U. L., Abu, E. K., Nwaeze, O., Oloruntoba, R., et al. (2020). Factors associated with the myth about $5 \mathrm{G}$ network during COVID19 pandemic in Sub-Saharan Africa. Journal of Global Health Reports, 4, e2020094. https://doi.org/10.29392/ 001c. 17606

Pal, R., Yadav, U., Grover, S., Saboo, B., Verma, A. and Bhadada, S. K. (2020). Knowledge, attitudes and practices towards COVID-19 among young adults with Type 1 Diabetes Mellitus amid the nationwide lockdown in India: A cross-sectional survey. Diabetes Research and Clinical Practice, 166, 108344. https://doi.org/10.1016/j.diabres. 2020.108344

Peng, Y., Pei, C., Zheng, Y., Wang, J., Zhang, K., Zheng, Z., et al. (2020). A cross-sectional survey of knowledge, attitude and practice associated with COVID-19 among undergraduate students in China. BMC Public Health, 20(1), 1292. https://doi.org/10.1186/s12889-020-09392-z

Pew Research Center. (2021). Internet use by age Available at: https://www.pewresearch.org/internet/chart/internetuse-by-age (Accessed: 3 September 2021).
Qutob, N. and Awartani, F. (2021). Knowledge, attitudes and practices (KAP) towards COVID-19 among Palestinians during the COVID-19 outbreak: A cross-sectional survey. PLoS One, 16(1), e0244925. https://doi.org/10.1371/ journal.pone.0244925

Reuben, R. C., Danladi, M. M. A., Saleh, D. A. and Ejembi, P. E. (2021). Knowledge, attitudes and practices towards COVID-19: An epidemiological survey in North-Central Nigeria. Journal of Community Health, 46(3), 457-470. https://doi.org/10.1007/s10900-020-00881-1

Rugarabamu, S., Ibrahim, M. and Byanaku, A. (2020). Knowledge, attitudes, and practices (KAP) towards COVID19: A quick online cross-sectional survey among Tanzanian residents. medRxiv, 2020.04.26.20080820. https://doi.org/ 10.1101/2020.04.26.20080820

Shrestha, A., Thapa, T. B., Giri, M., Kumar, S., Dhobi, S., Thapa, H., et al. (202). Knowledge and attitude on prevention of COVID-19 among community health workers in Nepal-a cross-sectional study. BMC Public Health, 21(1), 1424. https://doi.org/10.1186/s12889-021-11400-9

Singh, A., Purohit, B. M., Bhambal, A., Saxena, S., Singh, A. and Gupta, A. (2011). Knowledge, attitudes, and practice regarding infection control measures among dental students in Central India. Journal of Dental Education, 75(3), 421-427. https://doi.org/10.1002/j.0022-0337. 2011.75.3.tb05055.x

Tartari, E., Saris, K., Kenters, N., Marimuthu, K., Widmer, A., Collignon, P., et al. (2020). Not sick enough to worry? "Influenza-like" symptoms and work-related behavior among healthcare workers and other professionals: Results of a global survey. PLoS One, 15(5), e0232168. https://doi.org/10.1371/journal.pone.0232168

Ukaga, C. N., Sam-Wobo, S. O., Muhammed, R. H., Mogaji, H. O., Surakat, O. A., Suleiman, M. M., et al. (2021). Low first wave COVID-19 cases and health seeking behaviors across the six geopolitical zones of Nigeria. Nigerian Journal of Parasitology, 42(1), 1-8. https://doi.org/10.4314/njpar. v42i1.1

Umviligihozo, G., Mupfumi, L., Sonela, N., Naicker, D., Obuku, E. A., Koofhethile, C., et al. (2020). Sub-Saharan Africa preparedness and response to the COVID-19 pandemic: A perspective of early career African scientists. Wellcome Open Reserach, 5, 163. https://doi.org/10.12688/ wellcomeopenres.16070.1

WHO. (2021). Coronavirus disease (COVID-19) advice for the public: Myth busters. Available at: https://www.who.int/ emergencies/diseases/novel-coronavirus-2019/advice-forpublic/myth-busters (Accessed: 7 September 2021).

Wu, X.-L. and Munthali, G. N. C. (2021). Knowledge, attitudes, and preventative practices (KAPs) towards COVID-19 among international students in China. Infection and Drug Resistance, 14, 507-518. https://doi.org/10.2147/IDR. S291199

Zhong, B.-L., Luo, W., Li, H.-M., Zhang, Q.-Q., Liu, X.-G., Li, W.-T., et al. (2020). Knowledge, attitudes, and practices towards COVID-19 among Chinese residents during the rapid rise period of the COVID-19 outbreak: A quick online cross-sectional survey. International Journal of Biological Sciences, 16(10), 1745-1752. https://doi.org/10.7150/ijbs. 45221 
Zhou, P., Yang, X. L., Wang, X. G., Hu, B., Zhang, L., Zhang, W., et al. (200). A pneumonia outbreak associated with a new coronavirus of probable bat origin. Nature, 579, 270-273. https://doi.org/10.1038/s41586-020-2012-7 